\title{
REGISTERED NURSE TUTORS PERCEPTION OF THEIR ROLE
}

\author{
H. I. L. Brink
}

\begin{abstract}
The aim of this study was to determine how the registered nurse tutor in the Republic of South Africa perceives her role and how her role perception compares with the role expectations laid down by nurse leaders. A further question was whether a discrepancy existed between the tutors ideal role perceptions and her perceptions of whether the roles are acrually performed.

A survey by questionnaire was the method of investigation used. $A$ random sample stratified by population group and gender was selected from all nurses who had the additional qualification of nurse tutor entered against their name in the register of the $S$. A. Nursing Council.

The responding sample comprised 233 registered nurse tutors. Both descriptive and inferential statistics were used for the analysis of the responses. The findings suggested that the majority of registered nurse tutors perceived most of the role activities advocated by nurse leaders as ideal role
\end{abstract}

activities. However, a considerable number of respondents still consider the traditional teacher-centered role as ideal.

Only one-half of the respondents considered the scholarly role to be a distinct role component of the nurse tutor. Statistically significant differences between ideal and actually practised role perception scores were found on almost all role activities.

\section{OPSOMMING}

Die doel van hierdie studie was om te bepaal hoe die geregistreerde verpleegdosent in die Republiek van Suid-Afrika haar rol sien en hoe haar siening van haar rol vergelyk met die rolverwagtinge wat deur verpleegleiers gekoester word. ' $n$ Verdere vraag w'as of die dosent se siening van haar ideale rol en haar siening van hoe haar rol in werklikheid uitgevoer word, teenstrydig is.

'n Opname met behulp van in vraelys was die ondersoekmetode wat gebruik is. 'n Ewekansige steekproef. gestratifiseer volgens bevolkingsgroep en geslag, is getrek van alle verpleegkundiges teenoor wie se naam die addisionele kwalifikasie van verpleegdosent by die Suid-Afrikaanse Raad op Verpleging geregistreer is. Die respondentegroep het uit 233 geregistreerde verpleegkundiges bestaan. Beide beskrywende en afleihare statistieke is gebruik vir die ontleding van die antwoorde.

Die bevindinge het daarop gedui dat die meerderheid van verpleegdosente meeste van die rolaktiwiteite wat deur verpleegleiers voorgehou word as die ideale rolaktiwiteite beskou. 'n Aansienlike gedeelte van die respondente sien egter nog die tradisionele onderwyser-gesentreerde rol as die ideaal. Net die helfte van die respondente sien die vakkundige rol as in besliste komponent van die verpleegdosent se taak.

Ten opsigte van byna al die rolaktiwiteite, is statistiese beduidende verskille in die dosente se beskouing van die ideale rol en hul sienswyse oor hoe die rol uitgevoer word, gevind.

\section{INTRODUCTION}

There can be little argument with the fact that the expectations and demands of the nurse tutor's role have expanded considerably over the past few decades. itructural, organisational and ilosophical changes which have taken place in the nursing education system have brought about additional responsibilities and activities as well as variations in the approach of the nurse tutor to some activities. This is well documented in contemporary literature as is the resistance to change in nursing and nursing education. (Chinn and Benne (1976))

Little is known however about how the nurse tutor perceives her role in the changing environment and whether her role perception is in agreement with the role expectations laid down by contemporary nurse leaders and if this is so, whether the ideal role is actualised in practice. A need was therefore recognised to obtain clarity on this matter. This need for clarity on the nurse tutor's role was intensified with the entry during the early 1980 's of the nursing education system into the tertiary education system.

As the majority of nurse tutors had been socialised in nursing schools that were traditionally bureaucratic in nature and in programmes that were typically rigid, stereotyped and teacher-centred, concern was expressed whether the average nurse tutor would be committed to the changes advocated in the new system. Would her role perception and performance not still be influenced by the traditionally-hierarchy bound teacher-centred tutor role, rather than by the humanistic perspective and student-centred approach advocated in the tertiary education system? With these questions in mind it appeared pertinent to explore the role perception and performance of the registered nurse tutor. The nurse tutors' perception of her role should indicate her sensitivity to her changing role and to the changing pattern of nursing education and could expose any discrepancies in role expectations held by authorities and nurse leaders and the performed roles of the nurse tutor. Knowledge of this could facilitate decisions about the preparation, orientation, inservice and continuing education programmes appropriate to nurse tutors in the future.

\section{PROBLEM}

The problems investigated were: What does the registered nurse tutor perceive her role to be? How does her role perception compare with the role expectations laid down by nurse leaders? Is there a discrepancy between her ideal role perceptions and her perceptions that the roles are actually performed? To what extent are recommended changes involving the teaching-learning process utilised?

\section{OBJECTIVES}

A specific objective of the study was to identify and describe the registered nurse tutor's perception of her role functions.

\section{DEFINITION}

The concept registered nurse tutor as used in this study refers to all professional nurses who have had the additional qualification of nurse tutor entered behind their name in the South African Nursing Council register for tutors, regardless of whether they are actually engaged in formal teaching or not.

\section{THEORETICAL FRAMEWORK}

The theoretical framework for this study was grounded in role theory. Role theory is multidimensional, as anthropologists, psychologists, sociologists and philosophers have all contributed to the study of roles and have all considered the 
concept of role from a different perspective. Despite the diverse perspectives the technical definitions of the concept role do not differ radically from the ordinary usage of the concept. In a broad sense, role can thus be taken to mean a set or pattern of behaviours, values and attitudes associated with the incumbents of a particular social position

Three aspects or elements of any role have been identified in the literature and are outlined as (1) socially prescribed or ideal roles which refers to the role expected of incumbents of a particular position by society (2) perceived roles which focus on how a person defines the situation or believes he or she should behave in a given role. From this aspect it is not taken for granted that everyone accepts the prescribed behaviours and norms about a role or perceives them in the same way (3) performed role focuses on what role incumbents actually do. The actual performance of a role is dependent on many factors other than one's perceptions and beliefs about how it ought to be performed. The pressures and opportunities of a specific situation, for instance would influence how an individual performs the role. (Broom and Selznick 1973: 35-36). A persons role performance (actual behaviour) may be different from the way she perceives her role and this may not be identical to the socially prescribed or ideal role. Discrepancies between these aspects of a role may prove to be critical indices of personal stress experienced by those involved.

As the complexity and multiplicity of functions expand with change, several distinct role components may evolve. Each of these role components generally requires separate and distinct preparation competencies and commitments.

Commitment to role change according to Reinkemeyer (1970) can be deduced if individuals adapt positively to legitimate demands (ideal role).

All these aspects of role theory just described are relevant to this study because its purpose is to find out how the role of the nurse tutor is perceived by the occupants of that role.

\section{RELATED LITERATURE}

The role of the nurse tutor in the United Kingdom was examined by Sheahan in 1981. He undertook a survey by a selfdesigned postal questionnaire to determine how British nurse tutors and nurse learners perceive the role of the nurse tutor in the field of general nursing. Agreement was found between the teachers and the learners relating to the role of the nurse tutor on four of twelve factors, namely that the nurse tutor serves the function of a role model, that her approach should be learner-centred, that she should provide feedback to learners relating to examinations and testmarks, and that she should do research. In the areas of disagreements the learners put more emphasis on the moral and pastoral role than the tutors; they also perceived a clinical specialisation role as well as an element of library management in the role of the tutor which the teachers did not. The areas in which the teachers responses were more positive than the learners were in creating a learning environment; the assessment of learning; teaching research based nursing and the recruitment of learners (Sheahan 1981: 125-135).

A much quoted study in the USA on which several other studies pertaining to role conceptions have been based is one done by Corwin. He developed a Likerttype questionnaire which described three role conceptions -. bureaucratic, professional and service - all three of which may be held in varying degree by nurses. Corwin used the terms role frustration and role discrepancy to define a measurable characteristic of role conception which can lead to role conflict. Each of these terms was used to refer to the extent to which an ideal role conception is perceived to be nonoperative in actual practice. The discrepancy score is the difference between the respondents statement of what should be the case and his perception of what is actually the case. (Corwin and Taves 1962: 228). Corwin's study was directed at graduate and student nurses, not at nurse educators. He found that the type of role conception held, the certainty with which it is held and the amount of deprivation experienced, varied with different types of nursing education and in different stages of nursing careers.

Pieta in 1976 used an instrument adapted from the role conception scores developed and used by Corwin to examine nursing role conceptions as perceived by senior nursing students and their faculties. Similarities were found in the perception of the ideal role conceptions for the groups studied. Perceptions of actual practice were diverse among the groups (Ward and Fetler 1979: 425-427).

Data concerning teachers behaviour during teacher training workshops organised by the World Health Organisation over the last 10 years with participants from a great variety of geographical or socio-political backgrounds, clearly indicate that teachers are more like each other than they are like the people of the community to which they belong. (Guilbert 1981: 3-33) This implies general conformity to the prescribed roles of a teacher.

Ample examples were found in the literature on the multidimensional roles as well as the shift in role expectations concerning the nurse tutors and teachers in general. (Bell 1979; Clark 1978; Charles 1976; Christman 1980; Darkenwald and Merriam 1982; Durant 1978; Grimes 1982; Guilbert 1981; King 1961; King and Gerwig 1981; Kirschenbaum and Simon 1978; Knopke and Diekelmann 1978; Machan 1980; Mauksch and Styles 1982; Millard 1975; Miller 1979; Milligan 1972; National League of Nursing 1977; Quinn 1980; Searle 1977; Wallenborn 1980)

There appears to be general agreement among the various writers on the following distinct components of the nurse tutors role (teacher; clinician; scholar; counsellor and consultant). Each of these role components consist of distinct behaviours and values. The major shifts in role expectations were from the traditional image of the teacher who believes in teacher-directed learning, who regards the learner as a dependent object to be shaped and moulded and a passive recipient to be provided with knowledge and skills to the image of the humanistic teacher who believes in self-directed learning and thinks in terms of facilitating, assisting and encouraging the student's self-actualisation and considers each learner as an individual. No study was found which indicated to what extent the expected ideal had been implemented, or on the role perceptions of the nurse tutor in the RSA.

\section{METHOD OF STUDY}

The method of inquiry used in the study was that of a survey by questionnaires, details of these are given further on.

\section{SAMPLE}

A proportional stratified sampling desigh based on population group and gender was used to select 451 registered nurse tutors from a total population of 1312 . Two hundred and fifty-five persons responded and $233(17,5 \%$ of the total population) responses were found usable.

\section{THE RESEARCH INSTRUMENT}

The research instrument for this study which formed part of a comprehensive 5part questionnaire on several aspects concerning the nurse tutor was developed by the researcher. Part 2 of the questionnaire pertained to this study. This part was designed to elicit the respondent's perception of a nurse tutors role, botk. ideal and performed, to identify role discrepancies and also to establish to what extent recommended changes involving the teaching-learning process were being utilised. The role components identified the literature, as commonly agreed upon expected components of the nurse tutor's role were used as a basis for formulating the items. For each of the major role components described in the literature one or more role activities were listed. In addition the role activities of both the traditional and the humanistic teacher were included. This resulted in a list of 36 statements describing possible tutor activities.

The format used for this section was adapted and modified from the role conception scales originally developed and used by Corwin (1961: 69-86). Statements were formulated instead of the questions used by Corwin and a two column side-byside response format was designed to save respondents from having to read each item twice. Each of the statements describing a tutor activity was followed by two Likert type 5-points rating scales (strongly disagree - strongly agree) arranged side by side. On the first scale the respondent had to indicate the extent to which she agreed that the corresponding statement is 
the ideal for nursing education and on the second scale, the extent to which she agreed it is actually practised in the current situation. To insure more or less uniform interpretation of the 5 degrees of agreements, a key was included. (The questionnaire can be found in Brink 1984 Annexure B: 13-16).

The questionnaire was pretested on a representative convenience sample of 20 registered nurse tutors. Minor changes in wording and verb tenses were made on the recommendations of the pretestees.

\section{VALIDITY}

The instrument was considered to have content and face validity. First, the statements were a reasonably representative sample of nurse tutors role activities as discussed in the literature; second, all statements in this section of the questionnaire were assessed and evaluated for relevance by a panel of six experienced registered nurse tutors and scholars of the profession.

\section{RELIABILITY}

Internal reliability of both the perceived ideal and performed scale was determined by the use of Cronbach's alpha for each of the four major groups of registered nurse tutors who participated in the study. The results were as follows: College tutors ,97 and ,95; hospital tutors ,96 and ,96; university lecturers ,95 and, 95 and hospital matrons, 94 and ,95. As all values indicate high reliability, it was taken that the instrument permitted collection of consistent measures from each of the four groups.

\section{DATA COLLECTION}

The questionnaires were posted during October 1983 to the random selected sample of 451 registered nurse tutors. By January 198410255 questionnaires of mich 233 were usable had been returned.

\section{DATA ANALYSIS}

Both descriptive and inferential statistics were used for the analysis of the responses.

Initially each one of the 36 given statements was viewed separately for both scales. The responses in each of the scale categories were summed and the percentage value calculated for both the ideal and actual scales.

Participant's responses to the scales were then factor analysed to determine the existence of underlying traits or constructs and to confirm the validity of the given statements as attitudinal measures of the ideal role of the tutor. Factor analysis was conducted by using the principal components procedure followed by a Varimax rotation as described in the S.P.S.S. programme. Five factors were extracted. Convergence was reached after 11 iterations.

In view of the fact that the study group was composed of several distinct subgroups of registered nurse tutors, all functioning in different settings and thus subject to differing influencing factors, the possibility that one or two groups biased the findings could not be excluded. It was thus considered necessary to subdivide the study group into its major subgroups (viz. college tutors, hospital tutors, university staff and hospital matrons) and to analyse the responses of each subgroup separately. Participants responses to every item on both the perceived ideal and performed scale were summated separately on each scale category for each of the four subgroups to form scores that represented perceptions of the ideal and actually practised role activities.

Discrepancy in these scale scores (ideal perceived score minus ( - ) actually performed score) was computed item for item. The t-statistic was calculated to test the significance of the mean difference between the two scores for each item. Analysis of variance (ANOVA) computations were utilised to determine the existence of significant differences of role perception scores among the few groups. Sheffe's post hoc comparisons were used to measure the significance of differences.

\section{FINDINGS}

\section{Traditional teacher-centered roles}

The 4 (four) items which represented the traditional teacher-centered role component were concerned with whether a nurse tutor should (1) engage in expository teaching (transmit all information necessary to pass an examination); (2) constantly check on her students to ensure they are studying; (3) select instructional activities directed at the average student and (4) maintain a formal teacher-centered learning environment.

A mixed reaction was obtained.

Opinions were sharply divided with regard to item 1. Forty-four percent of the respondents agreed that this was the ideal, while 47 percent disagreed and the remainder were uncertain. More than onehalf of the respondents ( 59 percent) agreed with item 2, 68 percent agreed with item 3 while only one third agreed with item 4 , being an ideal role component. A much larger percentage however agreed that these activities were actually being carried out in practice $(63,5,63,8,63,7$ and 50,6 percent for items $1,2,3$ and 4

respectively.)

A comparison of the four major groups of registered nurses which constituted this sample (College tutors, hospital tutors, matrons and university staff) indicated that there were no significant differences among them in this perception of the ideal tutor role and the actually performed role of both the 0,05 and 0,01 levels of significance. $(F=1,187)$ This suggests that many tutors are still in transition from the teacher centered to the student-centered approach and even though it appears that the latter is perceived to be the ideal by many, a considerable percentage is still anchored in the traditional teachercentered approach.
Student-centered teacher role

The 12 items comprising this role component, were concerned with whether the nurse tutor should act as diagnostician, motivator, facilitator and resource person and whether she should involve the students in planning and in actively participating in class, whether she should permit creativity and should show tolerance for disagreement with her view, and whether she should be available for assistance when a student indicates a need for this. On this component the reaction was more or less homogeneous, with at least 90 percent of the respondents agreeing that the listed activities were the ideal. With regard to the tutor's perception as to whether those role-activities were actually performed, a much smaller percentage agreed that this was so approximately 40 percent and almost 25 percent were uncertain while the remainder disagreed. It appears however as though a large number of nurse tutors have not yet clearly defined their underlying philosophy. This was demonstrated in their responses to the traditional teachercentered items versus student-centered items. For example 58 percent of the respondents agreed that a tutor should constantly check on her students and 88 percent agreed that a tutor should allow and trust the students to assume responsibility for their own learning. These two statements are on opposite ends of a continuum. A tutor who allows and trusts her students to assume responsibility for their own learning would negate this trust if she constantly checked on them to ensure that they are studying what is prescribed. Yet at least 46 percent of the respondents perceived both these activities to be ideal role activities.

\section{Role components of consultant,} counsellor, role model and clinician There was more or less unanimous agreement among the respondents that a nurse tutor should act as consultant, counsellor, role-model and clinical supervisor with only 1,7 percent disagreeing and 3,9 percent expressing uncertainty in regard to this. However, only just over one-half of the respondents agreed that the first three activities were actually performed while only 40 percent agreed that tutors actually helped to supervise the students clinical practica. No significant differences were found among the four groups (college tutors, hospital tutors, matrons and university staff) with regard to perception of these role activities.

\section{Scholarly role}

The scholarly role was concerned with activities such as writing and publication of articles, conducting research, giving talks to professional and community groups, keeping abreast on matters relating to nursing practice and education, as well as issues and trends in higher education. Practically all respondents agreed that it was an ideal role. The mean response rate in actual performance of the items dealing 
with being well informed to issues and trends in nursing practice and education and higher education was $75 \%$, but only 50 percent to the statements which refer to writing publication and giving talks to professional groups and only 55 percent to the statement on conducting research. These findings may be accounted for by the fact that until very recently the scholarly role was not sufficiently emphasised in the tutor socialisation process and has thus not yet been firmly entrenched as a distinct role component of the nurse tutor.

\section{Other role activities}

Agreement was found between all respondents that a tutor should promote attitudes of mutual trust and respect between tutors and students and tutors and ward-staff and ward-staff and students; collaborate with mentors of other professions, participate in inservice and continuing education programmes in the service setting, socialise students, participate in professional and community activities, in the development and improvement of the nursing curriculum and in nursing school administration. However, a far smaller number ranging from 40-60 percent perceived these role activities to be actually performed in practice. Here too no significant difference in perception was found among the four subgroups.

In summary, the results of the data analysis presented above revealed the following:

Registered nurse tutors who participated in this study were aware of the tutor role requirements advocated by nurse leaders. The greater majority of respondents perceived the humanistically orientated student-centered role activities of the tutor as ideal role activities. This is congruent with the expectations of nurse leaders and consistent with the view of role theorists that despite each individual's uniqueness, high degrees of uniformity in beliefs, values and practices, usually do exist among members belonging to a specific professional group. The number of respondents who did not perceive the humanistic activities as ideal was small. It is not known whether they have not kept abreast of professional trends and issues and are thus unaware of the importance accorded to these activities in nursing education literature. This point requires further investigation.

Despite the fact that the majority of tutors surveyed believed that humanistically orientated role activities were appropriate to their functioning (ideal), statistically significant differences between ideal and actually practised role perception scores were found on all humanistic role activities. This indicates that the majority of tutors do not carry out in practice what they profess to believe. This finding is by no means unique to this country. Werner, in her study of nurse educators in the USA, found a

"tremendous credibility gap between what nurse educators believe and how they actually behave" (Cohen 1980: 169). The question is: "Why is this so?" Perhaps the environment in which they function needs to be investigated. A restrictive

bureaucratic organisation is not conducive to the development of humanistic education, which is based on autonomy, creativity and self-esteem. Questions such as, "Are they given sufficient support to implement these activities?" "Are they given opportunities to develop their knowledge about humanistic education and techniques?" need to be answered.

Even though statistically significant discrepancies were found between the perceived ideal and actually practised role, a small percentage of respondents did indicate that the ideal roles are carried out in practise. This is an important finding, though not statistically significant and deserves further attention. What are the variables that contribute to the implementation of ideal role concepts in the actual situation for one group, that may have been absent in the other group? Perhaps this needs to be investigated. On the other hand it may have been the more senior members in the survey who provided these responses?

The findings also indicated a general trend amongst the tutors surveyed to move away from traditional structured teaching activities. Although one-half still believed that these traditional activities were ideal for nursing education, the other half disagreed.

No significant discrepancies were found between the ideal and actually practised role with regard to traditional structured activities, which confirms the continued use of traditional practices and thus the continued traditional instruction of increasing number of students

Many of the study participants regarded both traditional teaching practices and student-centered teaching practices as ideal role requirements, even though these are contradictory in nature.

Significant discrepancies were found between the ideal and actually practised role perception on all other activities, in particular the following:

- involving students in planning and interpreting their own learning experiences

- offering regular opportunities for student self-evaluation

- being available in the practical situation to advise and guide students

- helping to supervise the students clinical experience

- being given turns to participate in aspects of nursing school administration

- writing articles on nursing for professional journals or

- conducting or participating in research activities.

The scholarly role did not appear to have been assimilated in the value system of the majority of tutors who participated in the study.

No significant differences were found among college tutors, hospital tutors, university lecturers and hospital matrons in their role perception with regard to both ideal and actually practised role.

It appears thus that no matter in which working situation the tutors find themselves, the majority are sensitive to their changing role, yet a large proportion do not yet regard it as always being implemented. Further research is required in this area.

\section{Acknowledgement}

In conclusion I wish to acknowledge the financial assistance received from the Human Sciences Research Council in this study.

\section{BIBLIOGRAPHY}

Barley, Z., Redman B., Faculty role development in university schools of nursing Journal of Nursing Administration, 1979 Vol. 9, no. 5, p. 43-47.

Bell D. Survey of the utilization of curriculum innovations in baccalaureate programs of nursing. Doctoral Dissertation. Saint Louis University: University Microfilms International. No. 7923808, 1979.

Benne K.D., Bennis W. The role of the professional nurse. American Journal of Nursing, 1979, Vol. 59, no. 2, p. 196-198.

Bevis M. Can faculty meet role expectations? in Current issues in nursing, ed. by McCloskey J.M., Grace H.K. Scranton: Blackwell Scientific Publications, 1981, p. 654-660.

Brink H.I.L. The registered nurse tutor in the Republic of South Africa. Doctoral thesis. University of South Africa. Pretoria, 1984.

Broom L., Selznick P. Essentials of sociology. New York: Prenctice-Hall, 1973.

Chinn R., Benne K.D. General strategies for effecting change in human systems in Bennis W.G. et al. (eds). The planning of change, $3 \mathrm{rd}$ ed. New York: Holt, Rinehart and Winston, 1976

Christman L. The practitioner/teacher in The practitioner-teacher role: practice what you reach. Ed. by L. Macham. Wakefield: Nursing Resources Inc., 1980.

Clark C.C. Classroom skills for nurse educators. New York: Springer, 1978.

Cohen $\mathrm{H}$. Authoritarianism and depending problems in nursing socialisation in Current perspectives in nursing, social issues and trends. Vol. 2, ed. by Flynn B.C., Miller H Saint Louis: Mosby, 1980, p. 159-170.

Corwin R.G. Role conceptions and career aspirations. A study of identity in nursing. Sociological Quarterly. 1961, Vol. 2, no. I, p.69-86.

Corwin R.G., Taves M. Some concomitants of bureaucratic and professional conceptions of the nurse role. Nursing Research. 1962, Vol. II, no. 11, p. 223-225.

Darkenwald G.G., Merriam S.D. Adult Education. Foundations of practice. New York: Harper Row, 1982.

Durant $L$. The student of nursing needs the consumer of education. Journal of Nursing Educarion. 1978, Vol. 17, no. 6, p. 15-19.

Grimes J.A. Curriculum theory: Basis for instructional decision making. Doctoral dissertation. State University of New York at Buffalo University Microfilms International No. 8211674, 1982.

Guilbert J.J. Educational handbook for health personnel. Geneva: WHO Offset Publication No. 35, 1981

Hardy M.E., Conway M.E. Role theory: perspective for health professionals. New York: Appleton-Century-Croft, 1983.

King I.M. Graduate education for the preparaton of teachers of nursing practice at 
the University of Illinois. Doctoral dissertation. Teachers College, Columbia University: University Microfilms Inc. No. 62-3552, 1961.

King V.G., Gerwig N.A. Humanizing nursing education. Wakefield Nursing Resources Inc

Kirschenbaum H., Simon S.B. Values and the futures movement in education, in Learning for to-morrow: the role of the future in education. ed. by Toffler, Al. New York: Vintage Books, 1974, p. 257-271.

Knopke H.J., Diekelmann N. L. Approaches to teaching in the health sciences. Reading: Addison-Wesley, 1978.

Machan I.. ed. The practitioner teacher role: Practice what you teach. Wakefield: Nursing Resources Inc., 1980.

Mauksch I.G., Styles M.H. From nurse to nurse educator: The socialization of nurses into the faculty role, in Nursing Education, ed. by Henderson M.S. New York: Churchill Livingstone, 1982.

Miller G.E., Fülop T. Educational strategies for the health professions. Geneva: WHO, 1974

Milligan J.B. Expectations of nursing faculty members in baccaleureate programs. Doctoral dissertation. Teachers College, Columbia University: University Microfilms, No. 732619.

National League for Nursing. Criteria for the appraisal of baccalaureate and higher degree programs in nursing. Fourth edition. New York: NLN, 1977.

Quinn F.N. The principles and practice of nurse education. London: Croom Helm, 1980.

Searle C. Nursing Educarion 1. Guide I.

Pretoria: Unisa, 1977

Wallenborn A.L. Preparing the practitioner as a teacher of nursing, in The practitioner-leacher role: Practice what you teach. ed. by Machan L. Wakefield: Nursing Resources Inc., 1980.

This article is based on part of the research undertaken in 1983 for the degree D. Litt. et Phil. with the University of South Africa.

Hilla Brink, D. Litt et Phil (S.A.)

R.N., R.M., R.T. R.N.A., C.H.N.

Professor in Nursing Education

Dept. of Nursing Science, University of S.A.

\section{CURRENT RESEARCH LOPENDE NAVORSING}

\section{Gemeenskapgesondheid}

Community Health

Norval, M.S.

Geskiedenis van die seremoniële plegtigheid in verpleging - geskiedenis van professionele ontwikkeling

UP, 1987

Norval, M.S.

Verpleging gedurende die Anglo-Boereoorlog

UP, 1987

\section{erpleegkunde}

Nursing

Bam, N.

Evaluation of the effectiveness of the health education provided by registered nurses in a family planning situation in a black urban community

M.A. (Cur.), UNISA, 1988

Bellad-Ellis, $P$.

The development of a profile of a successful student. A probable selection instrument

M.A. (Cur.), UNISA, 1988

Dippenaar, J.M.

Die verband tussen otitis media en borsvoeding

\section{RESEARCH/NAVORSING}

UP

Potgieter, M.E.C.

Kommunikasie in kritieke sorgeenhede UP, 1987

Sibisi, C.D.S.

The development of evaluation instruments for quality control in operating room nursing

M.A. (Cur.) UNISA, 1988

Swanevelder, J.P.; Geyer, N.M.

Kosteberaming van 'n chirurgiese intensiewe eenheid

UP

Van Niekerk, J.G.P.

'n Biografiese profiel van basiese gegradueerde verpleegkundiges in die Republiek van Suid-Afrika

UP, 1986

\section{COMPLETED RESEARCH} AFGEHANDELDE NAVORSING

Community Health

Gemeenskapsgesondheid

Koekemoer, R.T.

Die voedingspatroon van blanke bejaardes in die Germistonse munisipale gebied M.Cur., RAU, 1988

\section{Nursing \\ Verpleegkunde}

Calitz, M.J.W.E.

Voorligting ten opsigte van gehoorbeskerming by 'n kragstasie

M.Cur., RAU, 1988
Roos, A.M.E.

Stimulasiespel as onderrigmetode vir studentverpleegkundiges

M.Cur., RAU, 1988

Steyn, E.

Die bydrae van die kinderpsigiatriese verpleegkundige tot primêre geestesgesondheid M.Cur. RAU, 1988

Swart, T.

'n Behoeftebepaling vir tuisbevallings

M.Cur., RAU, 1988

Chipps, J.

Socialization of nursing students

M.Sc. (Nursing), UWITS, 1988

Kekana, A.T.K.

Geriatrics Development of a health care model for the aged's needs in Lebowa Ph.D. UWITS, 1988

Maponyane, M.T.

The utilisation of geriatric nursing services provided by the Soweto City Health Department Clinics - a nursing management perspective

M.A. (Cur.), UNISA, 1988

Van der Wal, D.M.

Affektiewe onderrig aan geselekteerde verpleegkolleges

M.A. (Cur.), UNISA, 1988

Van Wyk, N.C.

Die ontwikkeling van 'n verpleegkundige beramingsinstrument vir vroue met

karsinoom van die mammae

D.Soc. Sc. (Verpl.), UOVS, 1988

Venter, H.E.

'n Evaluering van die verpleegprosesbcnadering in psigiatriese verpleegkunde

M.Cur., UPE, 1988

Wannenburg, I.

Formative clinical evaluation of first-year students in fundamental nursing science D.Cur., UPE, 1988 